Medical Research Archives, Vol. 5, Issue 7, July 2017

Constituents and Activities of Acorus tatarinowii

\title{
Constituents and Activities of Acorus tatarinowii
}

Authors:

Yang Ruolin

Yan Zhonghong

Chen Congying

Liu Jianhua

\begin{abstract}
Affiliations:
Department of Chemistry, School

of Medicine, Shanghai Jiaotong

University, China
\end{abstract}

\section{Corresponding author:}

Liu Jianhua

\begin{abstract}
In this manuscript, chemical constituents, especially those with novel structures obtained from Acorus tatarinowii Schott (ATS), along with the pharmacological studies of those compounds, the volatile oil and the water soluble part of ATS, were reviewed.
\end{abstract}

Keywords: Acorus tatarinowii, Shichangpu 


\section{Introduction/Background}

In traditional Chinese medicine Shichangpu, the most frequently appeared component in Chinese medicine formulas to treat neurological diseases such as Alzheimer's disease (Hu et al. 2012), is a famous resuscitation drug, exhibiting functions of expectorant, resuscitating, awakening and promoting intelligence. The source of Shichangpu should be Acorus tatarinowii Schott (Pharmacopoeia of People's Republic of China, 2010). But confused species such as A. calamus L. and $A$. gramineus Soland are also found in market. On the other hand, "nine sections changpu" which source is Anemone altaica Fisch, is a pseudo specie of Shichangpu. Numerous studies have been done on Shichangpu including the chemical constituents, in vivo and in vitro pharmacological activity, combination therapy with other medicines and so on. Herein, the chemical and pharmacological studies of A. tatarinowii Schott (ATS), the main source of Shichangpu were reviewed.

\section{Chemical constituents of ATS}

At the beginning of the 20th century, chemical and pharmacological studies of ATS were mainly focused on the volatile oil fractions. Volatile oil is believed to be the active component of Shichangpu as a resuscitation drug. Since 2010, many new compounds have been reported with the advanced separation technology and identification of compounds in ATS with LC-MS/MS became possible as well (Zhang et al. 2014).

\subsection{Volatile oil \& phenylpropanoids}

The higher contents of the volatile oil of ATS are phenylpropanoids such as $\beta$-asarone $(\approx 80 \%), \quad \alpha$-asarone $(\approx 4 \%), \gamma$-asarone (syn. euasarone, $\approx 7 \%)$, methyleugenol $(\approx 1 \%)$, cis-methylisoeugenol $(\approx 3 \%)$, et al (Se et al. 2011), while the content of these compounds varies widely in different batches of herbs. By using GC-MS/MS, more and more volatile substances can be identified in ATS (Wang et al. 2012).
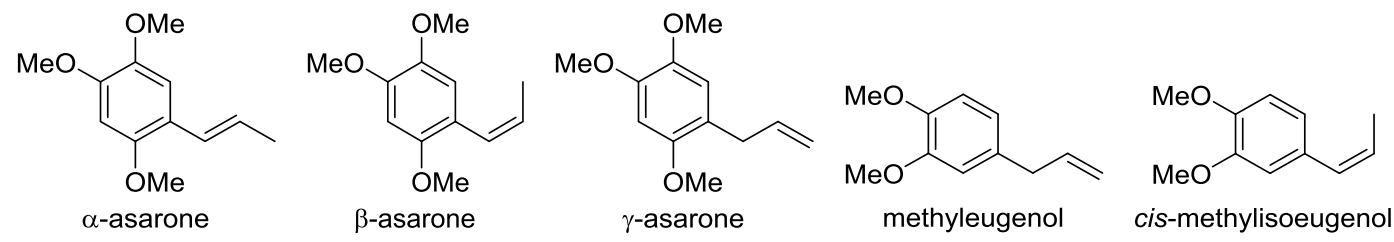

As a main class of secondary metabolites in ATS, a variety of phenylpropanoids had been reported. However, due to the relative simplicity of the structure, few derivatives with novel structure were reported. In 2000, Hu et al reported four

compounds named respectively as isoacoramone, cis-epoxyasarone, (threo)1',2'dihydroxyasarone and (erythro)1',2'dihydroxyasarone in which isoacoramone and cis-epoxyasarone were obtained as a mixture (Hu et al. 2000). 
Medical Research Archives, Vol. 5, Issue 7, July 2017

Constituents and Activities of Acorus tatarinowii

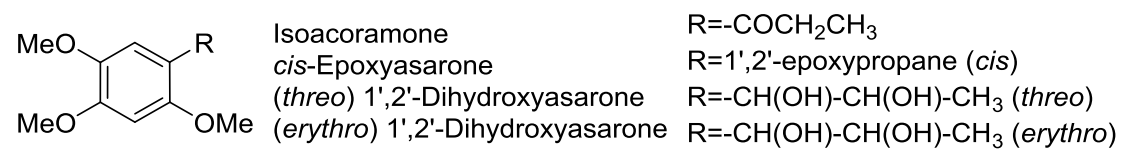

Tataramide A was reported as an amide of substituted cis-3-phenylacrylic acid (Wang et al. 1997). And another two novel amides of substituted cis- and trans-3-phenylacrylic acid were reported in 2015 without trivial names (Liang et al. 2015). Also, a new derivative of 2-methyl-3-phenyloxirane (2,4,5-trimethoxyl-2'-butoxy-1,2-phenylpro- pandiol) was reported by Zhu et al, with undefined configuration of the chiral carbons (Zhu et al. 2012). Tatarinoids A and B are novel phenylpropanoids with simple structure which are considered to be in equilibrium with each other via enediol intermediates (Tong et al. 2010).
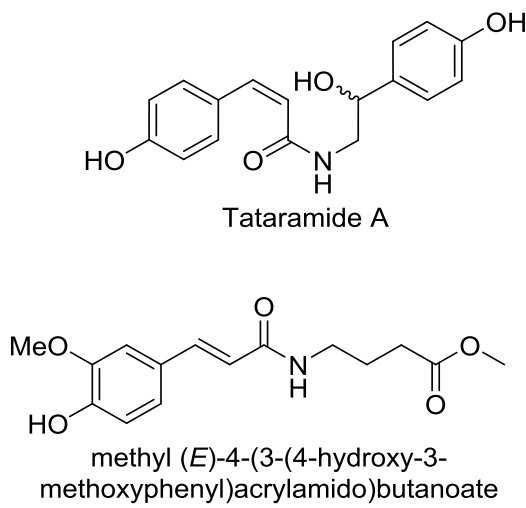

\subsection{Lignans}

In recent years, devised new lignans with new skeletons were reported by different groups. Many lignans were isolated and reported with their enantiomers such as $( \pm)$-acortatarinowins $\mathrm{A} \sim \mathrm{C}$ being reported as pairs of new 8-O-4'-type dinorneolignan enantiomers, $( \pm)$-acortatarinowins $\mathrm{D}$ and $\mathrm{E}$ as pairs of new 8-O-4'-type and rare C7-C8'-type neolignan enantiomers and $( \pm)$-acortatarinowin $\mathrm{F}$ as a pair of new bisepoxylignan enantiomers obtained along with known compounds ( \pm )-eudesmin ( $\mathrm{Lu}$ et al. 2015). Lu's group also reported other pairs of enantiomers such as $( \pm)$-acortatarinowins $G \sim \mathrm{I}$ in which $( \pm)$-acortatarinowin $G$ were rare 7,8'-epoxy-8,7'-oxyneolignane ( $\mathrm{Lu}$ et al. 2016). Recently, Qin's group reported identification of $( \pm)$-asarolignans $\mathrm{B}$ and $\mathrm{C}$, which were the first examples of naturally occurring 7-O-7'-type neolignans, along with another new lignan enantiomers ( \pm )-asarolignan G (Qin et al. 2017). 
Medical Research Archives, Vol. 5, Issue 7, July 2017

Constituents and Activities of Acorus tatarinowii<smiles>[R]Cc1ccc(O[C@H](C)[C@H](O)c2cc([R1])c(OC)c(OC)c2)c(OC)c1</smiles>

(+)-Acortatarinowin A R1 $=\mathrm{H}, 7 \mathrm{~S}$ (-)-Acortatarinowin B $\mathrm{R} 1=\mathrm{H}, 7 R$

$(+)$-Acortatarinowin C R1=OMe, $7 S$<smiles>[R]C(=O)c1ccc(O[C@H](C)[C@H](O)c2cc([R1])c(OC)c(OC)c2)c(OC)c1</smiles>

(-)-Acortatarinowin A R1=H, 7R $(+)$-Acortatarinowin B R1=H, 7S (-)-Acortatarinowin C R1=OMe, 7R<smiles>COc1cc(OC)c([C@H]2O[C@H](C)[C@H](c3cc(OC)c(OC)cc3OC)[C@H]2C)cc1OC</smiles>

$(+)$-Acortatarinowin E<smiles>C=CCc1ccc(O[C@H](CO)[C@H](O)c2ccc(OC)c(OC)c2)c(OC)c1</smiles>

(+)-Acortatarinowin D<smiles>C=CCc1ccc(O[C@H](CO)[C@@H](O)c2ccc(OC)c(OC)c2)c(OC)c1</smiles>

(-)-Acortatarinowin D<smiles>COc1cc(OC)c([C@H]2O[C@H](C)[C@H](c3cc(OC)c(OC)cc3OC)[C@H]2C)cc1OC</smiles>

(-)-Acortatarinowin E<smiles>[R1]c1cc([C@@H]2OC[C@@H]3[C@@H](c4cc([R])c(OC)c(OC)c4)OC[C@@H]23)cc(OC)c1[R3]</smiles>

$(+)$-Acortatarinowin $\mathrm{F} \mathrm{R}_{1}=\mathrm{R}_{2}=\mathrm{OMe}, \mathrm{R}_{3}=\mathrm{H}$ $(+)$-Eudesmin<smiles>[R2]c1cc([C@@H]2OC[C@H]3[C@@H](c4cc([R2])c(OC)c(OC)c4)OC[C@H]32)cc(OC)c1[R3]</smiles>

(-)-Acortatarinowin $\mathrm{F} \mathrm{R}_{1}=\mathrm{R}_{2}=\mathrm{OMe}, \mathrm{R}_{3}=\mathrm{H}$ (-)-Eudesmin $\quad \mathrm{R}_{1}=\mathrm{R}_{2}=\mathrm{H}, \mathrm{R}_{3}=\mathrm{OMe}$<smiles>COc1cc(OC)c([C@H]2O[C@H](C)[C@@H](c3cc(OC)c(OC)cc3OC)O[C@@H]2C)cc1OC</smiles>

(+)-Acortatarinowin G

(-)-Acortatarinowin G

(+)-Acortatarinowin $\mathrm{H}$<smiles>COc1cc([C@H]2O[C@H](c3cc(OC)c(OC)c(OC)c3)[C@H](C)[C@@H]2C)cc(OC)c1OC</smiles>

$(+)$-Acortatarinowin I<smiles>COc1cc([C@H]2O[C@H](c3cc(OC)c(OC)c(OC)c3)[C@H](C)[C@@H]2C)cc(OC)c1OC</smiles>

(-)-Acortatarinowin I<smiles>COC1=CC(=O)C2=C(C1=O)[C@@H](c1cc(OC)c(OC)cc1OC)C(C)C(C)=C2</smiles>

(-)-Acortatarinowin $\mathrm{H}$ 
Medical Research Archives, Vol. 5, Issue 7, July 2017

Constituents and Activities of Acorus tatarinowii<smiles>COc1cc(OC)c(C(O[C@H](C(C)O)[C@H](C)O)c2cc(OC)c(OC)cc2OC)cc1OC</smiles>

(+)-Asarolignan B

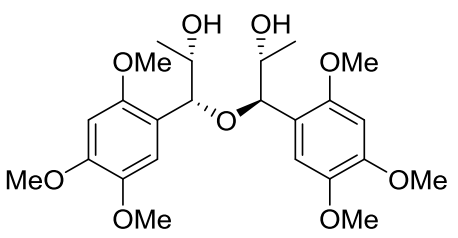

(+)-Asarolignan C

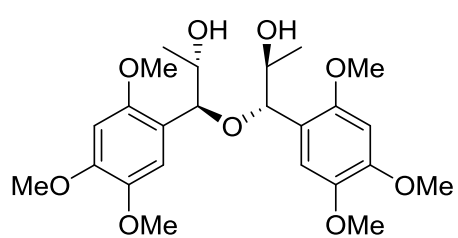

(-)-Asarolignan B<smiles>COc1cc(OC)c([C@H]2c3c(OC)cc(OC)c(OC)c3[C@@H](C)[C@@H](C)[C@@H]2C)cc1OC</smiles>

(+)-Asarolignan G<smiles>COc1cc(OC)c([C@H]2c3c(OC)c(OC)cc(OC)c3[C@@H](OC)[C@@H](C)[C@@H]2C)cc1OC</smiles>

(-)-Asarolignan G
Lignans were also obtained as racemic mixtures or a mesomer in some cases, such as
$( \pm$ )-asarolignans D F as racemates (Qin et al. 2017) and meso-asarolignan A as a mesomer.<smiles>CCC(c1cc(OC)c(OC)cc1OC)C(C)C(C)c1cc(OC)c(OC)cc1OC</smiles>

$( \pm)$-Asarolignan D<smiles>COc1cc(OC)c(OC)cc1/C=C/C[C@H](C)[C@H](OC)c1cc(OC)c(OC)cc1OC</smiles>

( \pm )-Asarolignan $E$

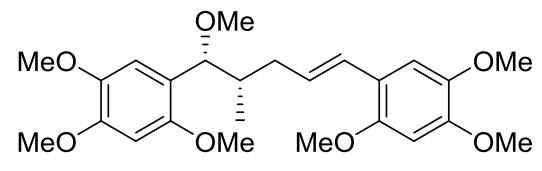

(士)-Asarolignan $\mathrm{F}$<smiles>COc1cc(OC)c([C@H](O[C@H](c2cc(OC)c(OC)cc2OC)[C@H](C)O)[C@H](C)O)cc1OC</smiles>

Tetrahydrofurans of 7-O-9'-type were also reported such as acortatarinowins $\mathrm{J} \sim \mathrm{L}$ along with acortatarinowins $\mathrm{M}$ and $\mathrm{N}$ (Lu et al. 2016). Tatarinan $S$ is a C8-C9'-type neolignan, which was naturally obtained for the first time in 2016 (Luo et al. 2016). New lignanamides were also reported such as tataramide B, tatarine E and acorusin A (Wang et al. 1997, Feng et al. 2016, Luo et al. 2016).

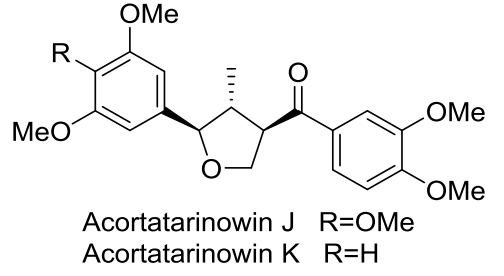

Acortatarinowin $\mathrm{J} \quad \mathrm{R}=\mathrm{OM}$ Acortatarinowin $\mathrm{K} \quad \mathrm{R}=\mathrm{H}$<smiles>COc1ccc(C(=O)C2COC(c3cc(OC)c(OC)c(OC)c3)C2C)cc1OC</smiles>

Acortatarinowin $\mathrm{L}$ 
Medical Research Archives, Vol. 5, Issue 7, July 2017

Constituents and Activities of Acorus tatarinowii<smiles>[R]c1cc(C(=O)OC)cc(OC)c1O[C@H](C)[C@H](O)c1cc(OC)c(OC)c(OC)c1</smiles>

Acortatarinowin $\mathrm{M} \mathrm{R}=\mathrm{OMe} 7 \mathrm{~S}, 8 \mathrm{R}$

Acortatarinowin $\mathrm{N} \mathrm{R}=\mathrm{H} \quad 7 R, 8 \mathrm{~S}$<smiles>CC[C@@H](/C(C)=C/c1cc(OC)c(OC)cc1OC)c1cc(OC)c(OC)cc1OC</smiles>

Tatarinan S<smiles></smiles><smiles>COc1cc([C@H]2Oc3c(OC)cc(C=CC(=O)NCCc4ccc(O)cc4)cc3[C@@H]2COC(C)=O)cc(OC)c1O</smiles>

Oligomeric lignans also present in ATS.

Tatanans A, B and $\mathrm{C}$ are novel sesquinlignans (Ni et al. 2011), while tatarinan $\mathrm{T}$ is dimeric lignan with the rare $\mathrm{C} 8-\mathrm{C} 7$ ' linkage pattern (Luo et al. 2016).<smiles>CC[C@H](c1cc(OC)c(OC)cc1OC)[C@@H](C)[C@H](/C(C)=C/c1cc(OC)c(OC)cc1OC)c1cc(OC)c(OC)cc1OC</smiles>

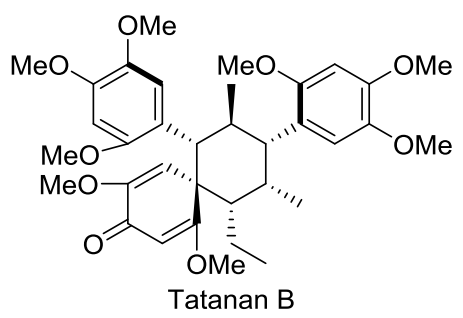

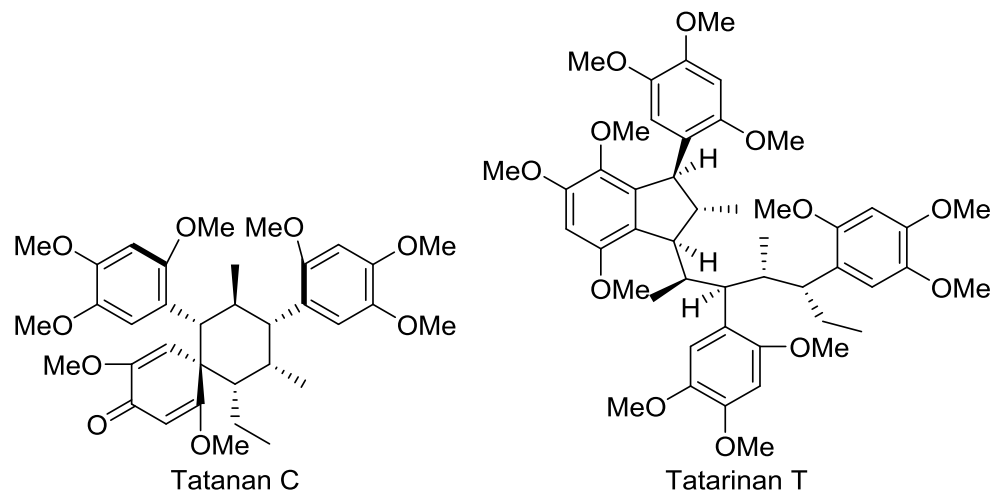


Besides normal lignans, some reported in 2010 (Tong et al. 2010), and norlignans have been reported as well. enantiomers of which were then separated by Acorusin B is an unusual hybrid-norlignan derivative with 5-hydroxymethyl-2chiral HPLC in 2017 (Qin et al. 2017). furaldehyde moiety ( $\mathrm{Ni}$ et al. 2016). Another novel norlignan without trivial name (-)-Tatarinoid $\mathrm{C}$ was a rare trinorlignan firstly was reported in 2015 (Liang et al. 2015).
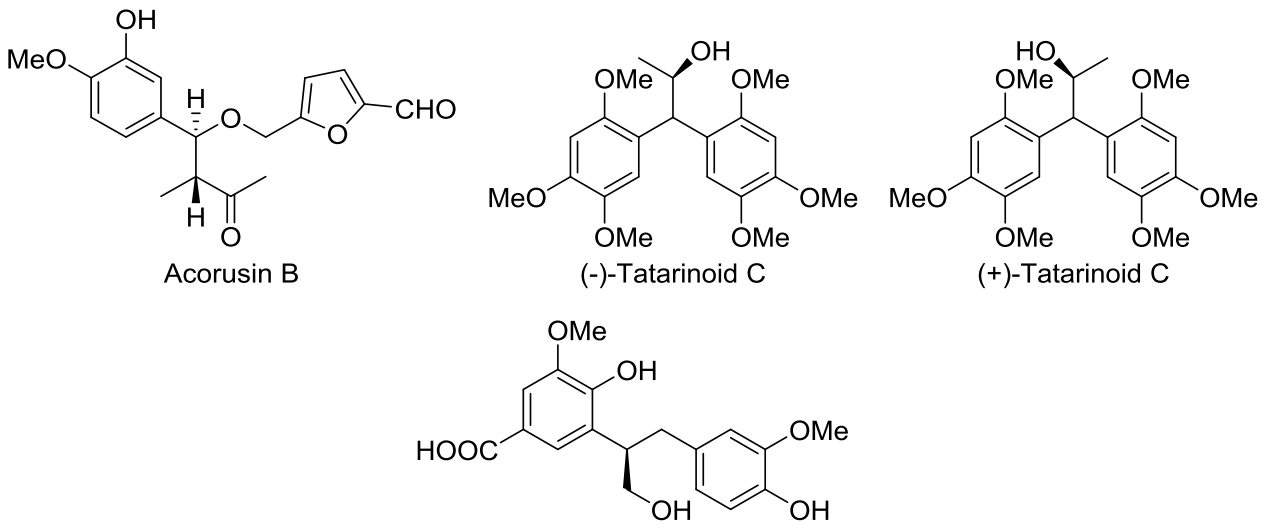

(R)-4-hydroxy-3-(1-hydroxy-3-(4-hydroxy-3-

methoxyphenyl)propan-2-yl)-5-

methoxybenzoic acid

\subsection{Sesquiterpenoids}

Skeletons of sesquiterpenoids in ATS are not abundant. Novel sesquiterpenoids mainly have three types of skeleton. New acorane-type sesquiterpenoids include tatanone A (Ni et al. 2013), acorusin D (Ni et al. 2016), 4-Epi-2-Hydroxyacorenone, 4-epi-2-acetoxyacorenone, acotatarone $\mathrm{A}$ and acotatarone B (Feng et al. 2014). Acorusin E, 1-hydroxy-7(11),9-guaiadien-8-one and acotatarone $\mathrm{C}$ are novel guaiane-type sesquiterpenoids (Feng et al. 2014, Ni et al. 2016, Zhu et al. 2010). New cadinane-type sesquiterpenoids tatarinowins $\mathrm{A}$ and $\mathrm{B}$ were reported in 2010 (Tong et al. 2010). Tatarinowin $\mathrm{C}$ is the 1,10-diol derivative of tatarinowin B obtained with acotatarone C (Feng et al. 2014). There may also be other stereoisomers and derivatives of tatarinowins $\mathrm{A}$ and B in ATS. Tatarinolacton is a novel sesquiterpene with an unprecedented epoxy lactone skeleton (Liang et al. 2015).

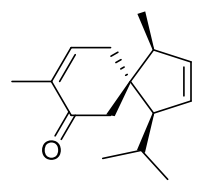

Tatanone A

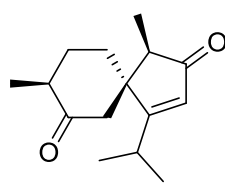

Acorusin D

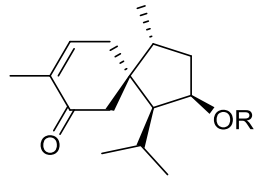

4-epi-2-Hydroxyacorenone $\mathrm{R}=\mathrm{H}$ 4-epi-2-acetoxyacorenone $\mathrm{R}=\mathrm{Ac}$

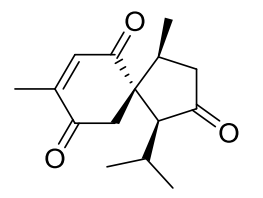

Acotatarone A

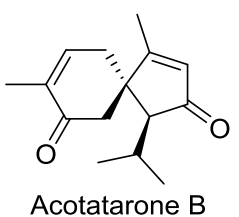


Medical Research Archives, Vol. 5, Issue 7, July 2017

Constituents and Activities of Acorus tatarinowii
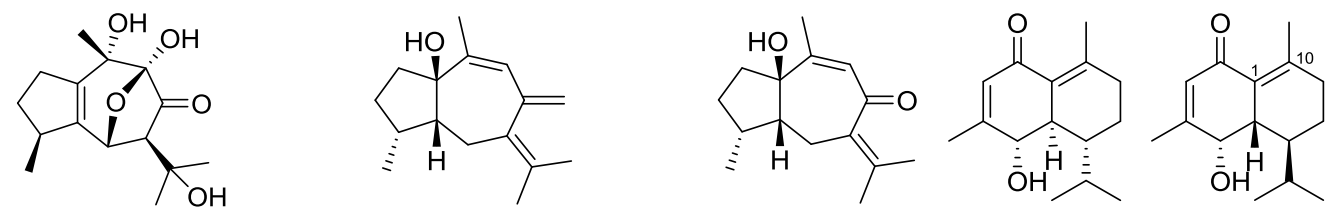

Acorusin $\mathrm{E}$

1-hydroxy-7(11),9-guaiadien-8-one

Acotatarone $\mathrm{C}$ Tatarinowin A

Tatarinowin B

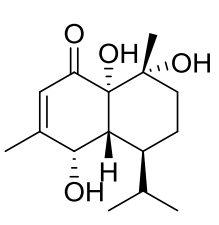

Tatarinowin C

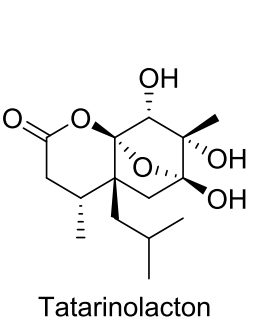

Tatarinolacton

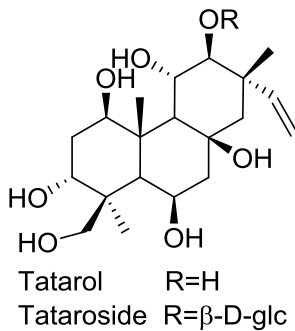

\subsection{Diterpenoids}

Abietane diterpenoid named as tatarol and its glucoside are the only two novel diterpenoids reported in the 1990s (Wang et al. 1997).

\subsection{Alkaloids}

Few novel alkaloids were reported besides the amides of phenylpropanoids.
Tatarinine $\mathrm{A}$ is a pyrazine derivative with five hydroxyl groups (Tong et al. 2010a). Acortatarins A and B were novel spiroalkaloids with naturally unusual morpholine motif reported by Tong's group in the same year (Tong et al. 2010b). Novel azafluoranthene alkaloid named as tatarine D was isolated from ATS with two known alkaloids tatarine A and telitoxine (Feng et al. 2016).<smiles>OCC(O)/C=C/c1cnc(CC(O)C(O)CO)cn1</smiles><smiles>Cc1ccc2n1C[C@]1(C[C@H](O)[C@@H](CO)O1)OC2</smiles>

Acortatarin A

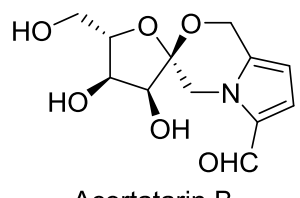

Acortatarin B

Tatarine A $\mathrm{R}_{1}=\mathrm{OH}, \mathrm{R}_{2}=\mathrm{H}, \mathrm{R}_{3}=\mathrm{H}$ $\begin{array}{ll}\text { Tatarine D } & \mathrm{R}_{1}=\mathrm{H}, \mathrm{R}_{2}=\mathrm{OH}, \mathrm{R}_{3}=\mathrm{H} \\ \text { Telitoxine } & \mathrm{R}_{1}=\mathrm{H}, \mathrm{R}_{2}=\mathrm{H}, \mathrm{R}_{3}=\mathrm{OH}\end{array}$<smiles>COc1cc(OC)c([C@@H]2[C@H](C)[C@@]3(CO)C=CC(=O)[C@@H]2O3)cc1OC</smiles>

Acorusin C

2.6 Anthraquinones, flavonoids, coumarins and triterpenoids

Known anthraquinones chrysophanol, physcion and emodin have been isolated from ATS (Zhu et al. 2010). Rhoifolin, astragalin, bergapten and other flavonoids, coumarins and triterpenoids such as cycloartenol, lupeol were also obtained (Tong et al. 2011). But none new anthraquinone, flavonoid, coumarin or triterpenoid was reported. 


\subsection{Miscellaneous}

5-Hydroxymethyl-2-furaldehyde and its derivatives, glucoside of benzyl alcohol were often obtained from ATS (Ni et al. 2013). Acorusin $\mathrm{C}$, which is a rare novel cycloheptenone oxide derivative was also identified (Ni et al. 2016).

\section{Pharmacological Study of ATS}

The rhizomes of ATS has been historically used to treat neurodegenerative diseases in China for thousands of years. In recent decades, in vivo and clinical pharmacological behaviors of Shichangpu have been widely studied. For example, in 2003 Sun's group reported a Chinese herbs formula which composed by Shichanpu, Gouqi and other seven herbs had great effects on improving the memory and cognitive function of AD-like animal model (Sun et al 2003). In the latest study Shichangpu showed an antidepressant effect on rat models by intragastric administration, and the mechanism of action (MOA) was supposed to be through upregulating motor, Akt, p70S6K or elF-4E protein expressions in the hippocampus (Wang et al 2016). However most pharmacological studies are based on the extract of ATS instead of the medicine.

\subsection{Activities of the volatile oil}

The volatile oil is considered to be the main active part of the ATS. So the pharmacological studies of ATS extract were mainly focused on the volatile oil in the past. It was used clinically for the treatment of unconsciousness such as pulmonary encephalopathy coma (Mao 2016). It was also been reported to have sedative, anticonvulsant activities in vivo and so on. Wu's group reported the volatile oil of ATS as well as $\beta$-asarone could significantly decrease the levels of blood cholesterol in atherosclerosis rat model and improve the blood rheological properties in hyperviscocity rats, while decrease ET level, and increase the NO content to reduce the degree of ischemic myocardial necrosis in myocardial ischemia rats, suggesting that the volatile oil and $\beta$-asarone had an important role of protecting the cardiovascular system (Wu et al. 2005). $\mathrm{Hu}$ 's group reported that ATS volatile oil could increase the permeability of blood-brain barrier (BBB) (Hu et al, 2009), and $\beta$-asarone, $\alpha$-asarone, cis-methylisoeugenol were confirmed to pass through the $\mathrm{BBB}$ along with the significant effects on a variety of learning and memory impairment models (Wu et al 2004). The volatile oil of ATS could also significantly improve the rat cortex convulsion threshold by the electrical stimulation which lasted longer than the positive control magnesium valproate with weaker effect. On the other hand, the expression of protein kinase $\mathrm{C}$ (PKC) was regulated by the volatile oil leading to reduction of nerve cell apoptosis, which was believed to be its MOA of the antiepileptic effect of the ATS volatile oil (Wang et al. 2015).

With macroporous resin, Zhou's group prepared different fractions of ATS to study the antidepressant effect of ATS extractions. The result showed only the fractions with abundant asarones were active (Zhou et al. 2015). $\alpha$-Asarone and $\beta$-asarone are two main components of the ATS volatile oil, which caused thorough studies of these two compounds and are the most detailed. Reviews on asarones showed $\alpha-$ and 
$\beta$-asarone could influence the nervous system, cardiovascular system, respiratory system and so on (Lan et al. 2013). Effect of combination of $\beta$-sarone and eugenol against PC12 cell injury induced by amyloid bata protein (A $\left.\beta_{25-35}\right)$ was also reported (Jiang et al 2006). Another research revealed that the anticonvulsant and sedative ingredient in ATS was eudesmin (Liu et al. 2015). Due to the fact that eudesmin is not a unique constituent of ATS, these results cannot explain the pharmacological activity of ATS comprehensively.

\subsection{Activities of the water soluble part}

In recent years, there were more researches on the activity of water soluble parts of ATS. Zhu's group revealed that the water extract of ATS could inhibit the exercise induced synthesis of 5-HT and TPH2 expression and prevent the exercise-induced decrease of 5-HT1B expression in the dorsal raphe of exercised rats (Zhu et al. 2014). In vitro activity study showed the hot water extract of ATS protected the differentiated PC12 cells against $A \beta$ induced toxicity by inhibiting the mitochondrial apoptotic pathway and reducing ROS generation (An et al. 2014). Cai's group revealed that the main components of the water decoction of ATS were $\beta$-asarone $(\approx 46 \%)$, 5-hydroxymethyl-2furaldehyde (33\%), et al (Cai et al. 2015). So it is not possible to determine whether the pharmacological activity of the water extract is attributable to asarone or other water-soluble compounds.

\subsection{Activities of the novel compounds}

\section{from ATS}

In order to find the lead compounds for drug discovery and development, novel compounds were reported frequently with various activities. Alkaloid acortatarins A could inhibit high-glucose-induced ROD generation in mesangial cells by almost $50 \%$ at the concentration of $10 \mu \mathrm{M}$ (Tong et al. 2010c). Alkaloids tatarines $A$ and $D$ inhibited $\mathrm{A} \beta_{42}$ aggregation with $\mathrm{IC}_{50}$ values of 45.0 and $26.0 \mu \mathrm{M}$, respectively, while the $\mathrm{IC}_{50}$ values of positive control epigallocatechin gallate (EGCG) were only $0.71 \mu \mathrm{M}$ (Feng et al. 2016).

Among the novel lignan enantiomers acortatarinowins $\mathrm{A} \sim \mathrm{F},(+)$-acortatarinowin $\mathrm{A}$, (+)-acortatarinowin $\mathrm{C}$ and (-)-acortatarinowin $F$ showed weak inhibitory activities against NO production in activated macrophages with $\mathrm{IC}_{50}$ values ranging from 23.3 to $29.5 \mu \mathrm{M}$. And $\mathrm{IC}_{50}$ values of positive control dexamethasone were $0.8 \mu \mathrm{M}$. More interestingly, in that study (-)-acortatarinowin F showed inhibitory effect, while $(+)$-acortatarinowin $\mathrm{F}$ was inactive ( $\mathrm{Lu}$ et al. 2015). Among acortatarinowins $\mathrm{G} \sim \mathrm{N}$ only acortatarinowin L showed antioxidant activity using DPPH reducing antioxidant power assay with $\mathrm{IC}_{50}$ value of $16.4 \pm 0.22 \mu \mathrm{g} / \mathrm{mL}$, while the $\mathrm{IC}_{50}$ value of positive control trolox was $3.895 \pm 0.38 \mu \mathrm{g} / \mathrm{mL}$ (Lu et al. 2016). Some lignans and phenylpropanoids were evaluated for anti-neuroinflammatory activities on TNF- $\alpha$ production in LPS-activated BV-2 cells. Asarolignan $\mathrm{G}$, tatarinoid $\mathrm{C}$ and $\left(7 R^{*}, 8 S^{*}\right),-7,8$-dihydroxy-asarone exhibited obvious inhibitory effects on the release of TNF- $\alpha$ at a concentration of $50 \mu \mathrm{M}$, suggesting the configuration was not critical to the antineuroinflammation activity in that case (Qin et al. 2017). Tatarinans T and S delayed the A $\beta$-induced paralysis in CL4176 transgenic $C$. elegans model at concentration 
of $100 \mu \mathrm{M}$, in which tatarinan $\mathrm{S}$ exhibited the higher protective effect, with its $\mathrm{PT}_{50}$ was $62.3 \%$ at $100 \mu \mathrm{M}$ and $30.8 \%$ at $10 \mu \mathrm{M}$, respectively (Luo et al. 2016). Tatanans A C displayed potent and selective in vitro $\mathrm{GK}$ activity higher than positive control GKA22 (Ni et al. 2011).

To identify the antidepressant compounds from ATS, assay for testing serotonin transporter (SERT) function was employed. Tatarinolactone significantly inhibited SERT activity (Liang at al. 2015). In vitro cytotoxicity of acorusins $\mathrm{B}, \mathrm{C}, \mathrm{E}$ and paeoniflorigenone against NCI-H1650, HepG2, BGC 823, HCT-116 and MCF-7 cell line exhibited moderate activities with $\mathrm{IC}_{50}$ values of 2.11 9.23 $\mu \mathrm{M}$ (Ni et al. 2016).

\section{Conclusion}

In the secondary metabolite research of ATS, lignans presents the highest probability of novel-compound occurrence. The high content of volatile oil in ATS caused the low contents of other kinds of compounds. So it is difficult to accumulate enough amounts of novel compounds for in vivo studies. On the other hand, lignans may have different levels of cytotoxicity, so it is difficult to carry out in vivo studies for in vitro active compounds without structural modification.

In the study of pharmacological activities of ATS, the volatile oil portion is still the most striking part. Although $\beta$-asarone is easy to pass through the BBB, with many experimental evidence indicating it is the active ingredient for the activities of ATS on the nervous system, it has the possibility to be carcinogenic, teratogenic and mutagenic. As a result, it is impossible to develop $\beta$-asarone alone to be a drug. In fact, volatile compounds of traditional Chinese medicine lose a lot in the boiling process. The actual amount of asarones into the human body is much lower than the content in the herbs. On the other hand, besides $\beta$-asarone, other volatile compounds in Shichangpu are also bioactive. Then, combination of $\beta$-asarone and other compounds may be promising research direction in the future.

From the existing literature, the in vivo study of ATS and the chemical research is often reported separately. So the chemical substance for treating nervous system disease of ATS has still not been fully confirmed. Many studies have shown that traditional Chinese medicine has the characteristics of multi-targeting, and interaction of multi-active substances. Therefore, the combination of active research and chemical composition analysis with statistical help such as partial least squares (PLS) may be helpful for clarifying the active ingredients of ATS. Then the quality standards of Shichangpu will be more accurate, and it will be easier to distinguish between its confused species and pseudo species.

\section{Acknowledgments}

The authors are grateful to the National Natural Science Foundation of China (81402775) and the grants from Shanghai Municipal Education Commission (12YZ054). 
Medical Research Archives, Vol. 5, Issue 7, July 2017

Constituents and Activities of Acorus tatarinowii

\section{References}

An HM, Li GW, Lin C. et al. Acorus tatarinowii Schott extract protects PC12 cells from amyloid- $\beta$ induced neurotoxicity. Pharmazie. 2014; 69(5):391-395. [PubMed: 24855834]

Cai XC, Gong YM, Deng GH, et al. Analysis of the components of Shichangpu decoction and concentrate. Sichuan Zhongyi. 2015; 33(6): 53-55.

Feng XL, Li HB, Gao H, et al. Bioactive nitrogenous compounds from Acorus tatarinowii. Magn Reson Chem. 2016; 54(5): 396-399. [PubMed: 26640008]

Feng XL, Yu Y, Gao $\mathrm{H}$, et al. New sesquiterpenoids from the rhizomes of Acorus tatarinowii. RSC Adv. 2014; 4: 42071-42077.

Hu J, Feng X. Phenylpropanes from Acorus tatarinowii. Planta Med. 2000; 66(7): 662-664. [PubMed: 11105577]

Hu Y, Yuan M, Liu P, et al. Effect of Acorus tatarinowii schott on ultrastructure and permeability of blood-brain barrier. Zhongguo Zhong Yao Za Zhi, 2009, 34(3): 349-351. [PubMed: 19445165]

Hu ZY, Huang Y, Liu G, et al. Analysis of medication law of Traditional Chinese Medicine in treating dementia. Zhongyao Yao Li yu Lin Chuang. 2012; 28(5): 252-256.

Jiang Y, Fang YQ, He YP. Protective effect of combination of effective components in Acorus tatarinowii on PC12 cell injured

by bata amyloid protein. Zhongyao Xin Yao yu Lin Chuang Yao Li, 2006, 17(5): 335-338.

an YR, Liu SX, Zhang TJ, et al. Research advances of asarone. Xiandai Yaowu yu Linchuang. 2013; 28(2): 252-257.

Liang S, Ying SS, $\mathrm{Wu} \mathrm{HH}$, et al. A novel sesquiterpene and three new phenolic compounds from the rhizomes of Acorus tatarinowii Schott. Bioorg Med Chem Lett. 2015; 25(19): 4214-4218. [PubMed: 26296476]

Liu H, Song Z, Liao DG, et al. Anticonvulsant and sedative effects of eudesmin isolated from Acorus tatarinowii on mice and rats. Phytother Res. 2015; 29: 996-1003. [PubMed: 25851178]

Lu Y, Xue Y, Chen S, et al. Antioxidant lignans and neolignans from Acorus tatarinowii. Sci Rep. 2016; 6:22909. doi: 10.1038/srep22909 [PubMed: 26961724]

Lu Y, Xue Y, Liu J, et al. ( \pm )-Acortatarinowins A-F, norlignan, neolignan, and lignan enantiomers from Acorus tatarinowii. $\mathrm{J}$ Nat Prod. 2015; 78: 2205-2214. [PubMed: 26305406]

Luo XH, Zhang YY, Chen XY, et al. Lignans from the roots of Acorus tatarinowii Schott ameliorate $\beta$ amyloid-induced toxicity in transgenic Caenorhabditis elegans. Fitoterapia. 2016; 108: 5-8. [PubMed: 26586617]

Mao JW. A review on effects of Shichangpu on central nervous system. Zhongyi 
Linchuang Yanjiu. 2016; 8(25): 143-145.

$\mathrm{Ni}$ G, Shen ZF, Lu Y, et al. Glucokinase-activating sesquinlignans from the rhizomes of Acorus tatarinowii Schott. J Org Chem. 2011; 76: 2056-2061. [PubMed: 21366319]

Ni G, Shi GR, Zhang D. et al. Cytotoxic lignans and sesquiterpenoids from the rhizomes of Acorus tatarinowii. Planta Med. 2016; 82(7): 632-638. [PubMed: 26848706]

Ni G, Yu DQ. Chemical constituents from rhizomes of Acorus tatarinowii. Zhongguo Zhong Yao Za Zhi. 2013; 38(4): 569-573. [PubMed: 23713285]

Qin DP, Feng XL, Zhang WY, et al. Anti-neuroinflammatory asarone derivatives from the rhizomes of Acorus tatarinowii. RSC Advances. 2017; 7: 8512-8520.

Se MY, Eun KK, Je HL, et al. Development of fingerprints for quality control of Acorus species by gas chromatography/mass spectrometry. Bull Korean Chem Soc. 2011; 32(5): 1547-1553.

Sun H, Hu Y, Zhang JM, et al. Effects of one Chinese herbs on improving congnitive function and memory of Alzheimer's disease mouse models. Zhongguo Zhong Yao Za Zhi. 2003, 28(8): 751-754. [PubMed: 15015359]

Tong XG, Cheng YX. Chemical constituents from Acorus tatarinowii. Nat Prod Res Dev. 2011; 23: 404-409.

Tong XG, Qiu B, Luo GF, et al. Alkaloids and sesquiterpenoids from Acorus tatarinowii. J Asia Nat Pro Res. 2010a; 12(6): 438-442. [PubMed: 20552480]

Tong XG, Wu GS, Huang CG, et al. Determination of absolute configuration by quantum computations and cAMP regulation activity. J Nat Prod. 2010b; 73:1160-1163. [PubMed: 20476749]

Tong XG, Zhou LL, Wang YH, et al. Acortatarins $\mathrm{A}$ and $\mathrm{B}$, two novel antioxidative spiroalkaloids with a naturally unusual morpholine motif from Acorus tatarinowii. Org Lett. 2010c; 12(8): 1844-1847. [PubMed: 20329735]

Wang MF, Lao AN, Wang HC. Two new isopimarane diterpenes from the roots of Acorus tatarinowii Schott. Chinese Chemical Letters. 1997; 8(1): 37-38.

Wang K, Yang Y, Liang Z, et al. The research on anticonvulsive effect and on the influence of the hippocampal PKC expression in epilepsy rat of the volatile oil of Acorus tatarinowii Schott. Zhangyao Yaoli yu Linchuang. 2015; 31(1): 97-100.

Wang Y, Chang L, Zhao X, et al. Gas chromatography-mass spectrometry analysis on compounds in volatile oils extracted from Yuan Zhi (Radix Polygalae) and Shi Chang Pu (Acorus tatarinowii) by supercritical $\mathrm{CO}_{2}$. J Tradit Chin Med. 2012; 32(3):459-64. [PubMed: 23297573]

Wang P, Wu YM. Effects of Rhizoma Acori tatarinowii (Shi Chang Pu) on expression of mTOR signaling pathway related 
protein in hippocampus of depression model rats. Zhongguo Linchuang Yixue. 2016; 23(5): 625-628.

Wei G, Fang YQ, Liu DH, et al. Study on GC-MS fingerprint analysis in rhizome of volatile oil of Acorus tatarinowii. Zhongguo Zhong Yao Za Zhi. 2004; 29(8): 764-768. [PubMed: 15506289]

Wu B, Fang YQ. Study on Acorus tatarinowii Schott chemical base and mechanism of enhancing intelligence. Zhangyiyao Xue Kan. 2004, 22(9): 1635-1636.

Wu Q, Fang Y, Chen Y, et al. Protective effects of volatile oil of Acorus tatarinowii Schott and $\square$-asarone on cardiovascular system. Zhongyao Xinyao yu Linchuang Yaoli. 2005; 16(4): 244-247.

Zhang F, Qi P, Xue R, et al. Qualitative and quantitative analysis of the major constituents in Acorus tatarinowii Schott by HPLC/ESI-QTOF-MS/MS. Biomed Chromatogr. 2015; 29:890-901. [PubMed: 25354491]
Zhou Y, Zhu X, Deng Y, et al. Correlation study on high performance liquid chromatography and antidepressant effect of different eluting fractions of Acorus tatarinowii Schott macroporous resin. Chongqing Yixue. 2015; 44(32): 4490-4492.

Zhu M, Tan N, Ji C, et al. Chemical constituents from petroleum ether fraction of ethanol extract of Acorus tatarinowii. Zhongguo Zhong Yao Za Zhi. 2010; 35(2): 173-176. [PubMed: 20394287]

Zhu M, Tan N, Xiong J, et al. Chemical constituents contained in ethanol extracts from Acorus tatarinowii and their anti-fatigue activity. Zhongguo Zhong Yao Za Zhi. 2012; 37(19): 2898-2901. [PubMed: 23270229]

Zhu M, Zhu H, Tan N, et al. The effects of Acorus tatarinowii Schott on 5-HT concentrations, TPH2 and 5-HT1B expression in the dorsal raphe of exercised rats. J Ethnopharm. 2014; 158: 431-436. [PubMed: 25456438] 